\title{
Pre-Harvest Application of Plant Biostimulant on the Quality and Shelf-Life of Yellow Melon (Cucumis melo L.)
}

\author{
Edna M. M. Aroucha ${ }^{1}$, Cleiniane M. G. de Sousa ${ }^{1}$, José Francismar Medeiros ${ }^{1}$, Glêidson B. de Góes ${ }^{1}$, \\ Iarajane B. do Nascimento ${ }^{1} \&$ Nícolas O. de Araújo $^{2}$ \\ ${ }^{1}$ Federal Rural University of Semi-Arid, Mossoró, RN, Brazil \\ ${ }^{2}$ Federal University of Viçosa, Viçosa, MG, Brazil \\ Correspondence: Nícolas O. de Araújo, Federal University of Viçosa, Viçosa, MG, Brazil. E-mail: \\ nicolas.araujo@ufv.br
}

Received: October 4, 2017

Accepted: December 17, 2017

Online Published: January 15, 2018

doi:10.5539/jas.v10n2p252

URL: https://doi.org/10.5539/jas.v10n2p252

\begin{abstract}
The purpose this work was to evaluate the influence of pre-harvest application of plant biostimulant on the quality and shelf-life of melon. For this an experiment was established in the "Coopyfrutas", located in Rio Grande do Norte state/Brazil. The treatments consisted of a combination of factors: melon cultivars ('Goldex' and 'Iracema') and pre-harvest application of plant biostimulant, Crop Set ${ }^{\circledR}$, (with and without). At commercial maturity, some fruit of each treatment were sampled and analyzed and the others were stored in a cold chamber at $10 \pm 2{ }^{\circ} \mathrm{C}$ and $80 \pm 2 \%$ relative humidity. The experiment was arranged in a completely randomized split-plot design. The plots consisted of cultivars and Crop Set ${ }^{\circledR}$ application and subplots of different storage time $(0,14$, 21,28 , and 35 days after harvest) with eight replications. The characteristics evaluated were length, diameter, internal cavity, external and internal appearance, weight loss, fresh firmness, soluble solids, titratable acidity, $\mathrm{pH}$, SS/TA ratio, and total soluble sugars. Applications of plant biostimulant led to an increase in fruit length and diameter. It reduced fresh firmness and increased the $\mathrm{pH}$ of 'Goldex' fruit. The total soluble sugars reduced at 35 days of storage in the 'Iracema' fruit treated with plant biostimulant.
\end{abstract}

Keywords: appearance, Goldex, Iracema, soluble solids, sugars

\section{Introduction}

Melon (Cucumis melo L.) is a vegetable of African and Asian origin, greatly appreciated and highly popular worldwide. Today melon cultivars are found in various regions, and this amplitude is a consequence of genetic variability that has allowed the adaptation of different types of melon to different conditions, so that today the fruit have specific characteristics, according to their group and cultivar.

The cultivation of melons of the Inodorous group is more common than that of Cantaloupensis in the agricultural region of Mossoró-Assu, Rio Grande do Norte, Brazil, the state of largest domestic melon production. Melons are fresh fruits most exported in term of volume from Brazil, the main market being the European Union, followed by North America (Sousa et al., 2013).

The economic importance of the crop has stimulated the intensification of research on procedures pre-harvest (Deng et al., 2013; Hayata et al., 2000), physiology, biochemistry (Moing et al., 2011; Obando-Ulloa et al., 2009) and post-harvest storage of melon (Liu et al., 2004; Tomaz et al., 2009; Zhang et al., 2017). In this regard, the use of plant growth regulators can modify the morphological and physiological processes in the fruit (Taiz \& Zeiger, 2009) at concentrations far below (Davies, 2010) by affecting crop growth and development, stimulating cell division and increasing nutrient and water uptake (Shin et al., 2007).

In Brazil, the sale of plant hormones for agriculture is not allowed. Therefore, in the literature, few studies have addressed the pre-harvest application of plant growth regulators in relation to the post-harvest quality of melon fruit. In other crops however, natural extracts with micronutrients (Crop Set $\left.{ }^{\circledR}\right)$ and action similar to cytokinins have been used with positive results in increasing fruit size and weight.

The commercial product Crop Set ${ }^{\circledR}$ (Improcrop-Kentucky-USA) is a plant biostimulant consisting of agave (Yucca Shidigera) extracts and mineral micronutrients with cytokinin-like action (Leão et al., 2005). According to 
the manufacturer's information, the commercial product Crop Set ${ }^{\circledR}$ is registered in Brazil as foliar fertilizer, containing $1.5 \%$ manganese, $1.5 \%$ iron and $1 \%$ copper.

Three hormones, auxins, gibberellins, and cytokinins are involved in the retention of young fruit on the plant and in the promotion of fruit growth by enhanced cell divisions and cell enlargement (Crane, 1964). Previous evidence reports the occurrence of cytokinin- like activity in fruit (Arnau et al., 1999), but our knowledge concerning the influence of pre- harvest application of plant regulators on the quality and shelf life is still scarce.

According with Hayata et al. (2000), the CPPU application pre-harvest increased fruit growth in Tokyo Earl's 55' melon in the first 10 days after anthesis and application of CPPU [N-(2-chloro-4-prydyl)-N-phenylurea] at the studied doses $\left(1,5\right.$, and $\left.10 \mathrm{mg} \mathrm{L}^{-1}\right)$. In this study no correlation with the shelf-life fruit.

On the other hand, during the post-harvest of fruit and vegetables the most common problems are associated with changes in flavor, fresh firmness (Amaro et al., 2013; Goulao et al., 2007) and total soluble sugars (Shin et al., 2007) and weight loss (Goulao et al., 2007). These characteristics are strongly influenced by time, temperature and relative humidity during storage. Thus, post-harvest techniques that reduce the metabolic activity could be a possibility to increase the shelf-life of the fruit.

Given the lack of studies published on the effect of the use of plant stimulant on the features and storage of melon fruit, the aim of this study was to evaluate the influence of pre-harvest application of the plant biostimulant Crop Set ${ }^{\circledR}$ on the quality and storage of yellow melon 'Goldex' and 'Iracema'.

\section{Method}

The experiment was conducted on the Farm Jardim, "Coopyfrutas", located in Mossoró, Rio Grande do Norte, Brazil. Seeds of the two melon cultivars 'Iracema' and 'Goldex' of the group Inodorus were used. The treatments consisted of two applications of the plant biostimulant Crop Set ${ }^{\circledR}$ sprayed with a backpack sprayer $(20 \mathrm{~L}, 8 \mathrm{~mL}$ of diluted Crop Set $\left.{ }^{\circledR}\right) 18$ days after transplanting (DAT) and $16 \mathrm{~mL}$ of Crop Set ${ }^{\circledR} 25$ DAT, applying the product regularly on the plants, always in the same way.

After 65 days of seedling transplanting, the fruits were harvested, classified according to size and then transported to the Laboratory of Food Technology of the Federal Rural University of Semi-Arid where part of the fruit were characterized previously by sampling eight fruit per treatment and the other part was stored in a cold chamber at $10 \pm 2{ }^{\circ} \mathrm{C}$ and $\mathrm{RH} 80 \pm 2 \%$, for $14,21,28$, and 35 days. After each storage time, the fruit quality was evaluated.

The experiment was set up in a completely randomized split-plot $(2 \times 2 \times 5)$ design. The plots consisted of cultivars, application of the plant growth regulator Crop Set ${ }^{\circledR}$ (with and without), and in the subplot time of post-harvest storage $(0,14,21,28$, and 35 days after harvest), with eight replications.

The fruit were evaluated after harvest for: weight $(\mathrm{g})$, length, diameter and internal cavity $(\mathrm{cm})$, weight loss (WL), result express in \%; external appearance (EA) and internal appearance (IA), a visual and subjective 1-5 grade scale was adopted, according to the severity of the defects in the outer area (depressions, wilt, fungal lesions or chilling injury) and internal (internal collapse, seed loss and/or fluid in the seed cavity) of the fruit: $1=$ extremely severe defect (above 50\% of fruit affected); $2=$ severe defect $(31-50 \%) ; 3=$ moderate defect $(11-30 \%)$; $4=$ mild defect $(1-10 \%)$; and $5=$ no defects; Fresh firmness (FF), a manual penetrometer (Mc Cormick Model 327 FT) was used and the results were expressed in Newton (N); Soluble solids (SS) were measured with a refractometer (PR - 100, Palette, Atago CO., LTD., Japan) and results expressed in percentage (\%); titratable acidity (TA) was analyzed by titrimetry and results expressed in $\%$ of citric acid; $\mathrm{pH}$ was determined in the juice of the fruit of each treatment using a digital potentiometer with glass membrane, calibrated with buffers of $\mathrm{pH} 7$ and 4 (AOAC, 1992); the SS:TA ratio was determined by ratio between soluble solids and titratable acidity. For total soluble sugars (TSS), the Antrona method was used, as described by Yemn and Willis (1954), expressing results in percentage (\%).

Analyses of variance were performed using the $\mathrm{F}$ test and means compared by the Tukey test at $\mathrm{p}<0.05$ probability trough software Sisvar 5.3 (Ferreira, 2010). The regression analysis was made using the Table Curve software (Jandel Scientific, 1991).

\section{Results and Discussion}

Effect of application of the plant biostimulant Crop Set ${ }^{\circledR}$ was observed on the fruit diameter and an effect of cultivar on fruit cavity. Also, the interaction between the factors biostimulant application and cultivar was significant for fruit length. 
During fruit storage after harvest, time had an isolated effect on the characteristics weight loss, external appearance, soluble solids and $\mathrm{pH}$. The effect of the interaction cultivar $\mathrm{x}$ storage time was significant on internal appearance, fresh firmness, titratable acidity and SS:TA ratio of fruit. The interaction cultivar and biostimulant application on fresh firmness and $\mathrm{pH}$ was also significant, as well as the interaction effect of the three factors cultivar, biostimulant application and storage time on total soluble sugars.

The behavior of cultivars differed for average fruit length, depending on the application Crop Set ${ }^{\circledR}$ (Table 1). In Iracema fruit, Crop Set ${ }^{\circledR}$ application induced a length increase of $18.21 \%$ compared to fruit without growth regulator. Likewise, the use of Crop Set ${ }^{\circledR}$ in 'Thompson Seedless' grapes induced an $11.78 \%$ length increase of the berries (Leão et al., 2005). The further development of the fruit after Crop Set ${ }^{\circledR}$ application can be explained by its cytokinin-like action, inducing cell division and thus stimulating cell growth in plant tissues.

Table 1. Means of length, pulp firmness and hydrogen potential as related to the application of Crop Set ${ }^{\circledR}$ in melon cultivars 'Goldex' and 'Iracema'

\begin{tabular}{lll}
\hline & Application of Crop Set ${ }^{\circledR}$ & No application of Crop Set $\mathbb{}$ \\
\hline $\begin{array}{l}\text { Length }(\mathrm{cm}) \\
\text { 'Goldex' }\end{array}$ & $18.70^{\mathrm{Aa}}$ & $18.05^{\mathrm{Aa}}$ \\
'Iracema' & $19.28^{\mathrm{Aa}}$ & $16.31^{\mathrm{Bb}}$ \\
\hline Pulp firmness $(N)$ & $15.22^{\mathrm{Bb}}$ & $16.37^{\mathrm{Aa}}$ \\
'Goldex' & $16.02^{\mathrm{Aa}}$ & $15.98^{\mathrm{Aa}}$ \\
'Iracema' & $5.73^{\mathrm{Aa}}$ & $5.59^{\mathrm{Ab}}$ \\
Hydrogen potential & $5.48^{\mathrm{Ba}}$ & $5.53^{\mathrm{Aa}}$ \\
'Goldex' & 'Iracema'
\end{tabular}

Note. Means followed by the same letter do not differ by the Tukey test at $\mathrm{p}<0.05$ probability. Uppercase letters compare averages within the column and lowercase letters within rows.

The application of biostimulant Crop Set ${ }^{\circledR}$ to the plants induced a 7\% decrease in pulp firmness (PF) of Goldex (Table 1). On the other hand, the application or not of biostimulant Crop Set ${ }^{\circ} \operatorname{did}$ not influence the firmness in 'Iracema' melon (Table 1). Kohatsu (2007) found lower PF in 'Galia' melon after kinetin application to plants, which was attributed to a possible hormonal imbalance, because when applied to the plants together with gibberellic acid, kinetin and IBA, the fruit had firmer pulp.

At harvest ( 0 days), the 'Iracema' melons were firmer compared to 'Goldex' melon. However, throughout the storage, there was a decrease in fruit firmness and the lowest PF value $(12.12 \mathrm{~N})$ was verified in the 'Iracema' melon at 35 days of storage (Figure 1A). The maintenance of PF is essential because firmer fruit are more resistant to mechanical damage. It is a characteristic influenced by fruit ripening, post-harvest handling and the plant material. In this study, the PF of 13.34 and 12.12 for the cultivars 'Goldex' and 'Iracema', respectively, ensured the marketing quality of the fruit until the end of storage.

For 'Iracema' fruit there was no difference between the average hydrogen potential $(\mathrm{pH})$ with and without Crop Set ${ }^{\circledR}$ application to plants (Table 1). However, the average $\mathrm{pH}$ of 'Goldex' fruit increased by $2.44 \%$ after Crop Set ${ }^{\circledR}$ application to plants. In Galia melon, hybrid 'Galileu', Kohatsu (2007) found an increased fruit pH (6.63), after kinetin application, exceeding the values detected in this work.

The titratable acidity (TA) of the fruit of the cultivars 'Iracema' and 'Goldex' at the end of storage was $0.102 \%$ and $0.093 \%$, respectively (Figure 1B). Analyzing the citric acid levels in melon cultivars, Nuñez-Palenius et al. (2007) found values between 0.08 and $0.15 \%$, and highest values $(0.21 \%)$ in the pulp of 'Galia' melon, in contrast with the result of this study with yellow melon. Although the acidity influence the melon fruit flavor (Cohen et al., 2014), small variations in acidity levels are little significant for melons and watermelons, due to the low concentration.

The average grades of the external appearance (EA) of the fruit decreased during shelf-life, regardless of the cultivar (Figure 2B). Despite the lower grade of EA, all fruit continued in excellent condition for sale, with grades above 3.0 (light depressions or spots on the fruit surface). 
Taking into account that the external appearance is a key feature for melon import firms and that fruit produced in northeastern Brazil takes 14-21 days to reach the shelves of major supermarkets in the US where they are purchased, on average, within three days and consumed soon by consumers, it appears that the fruit could be marketed without problems if stored under the conditions of this work.
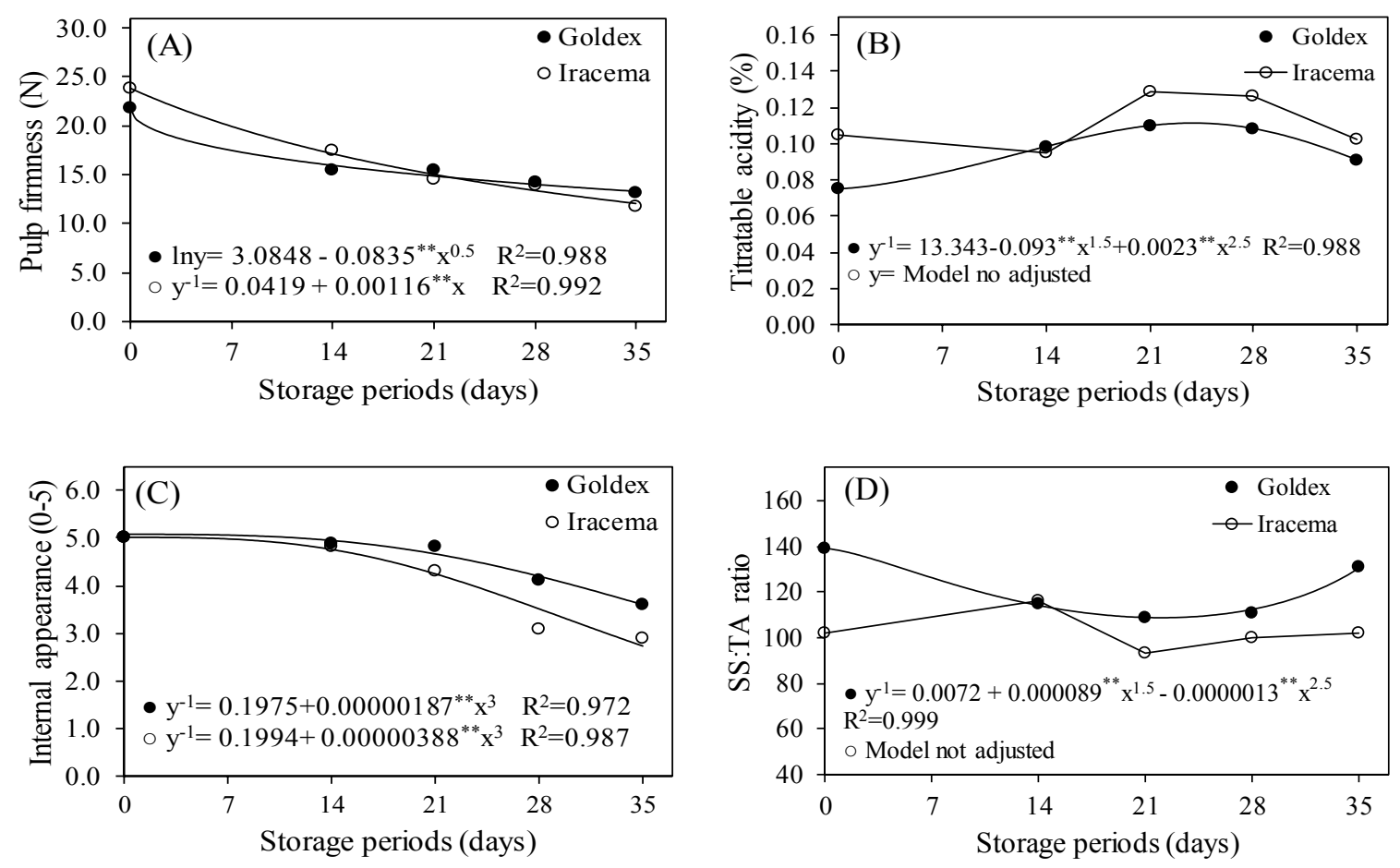

Figure 1. Pulp firmness (A), titratable acidity (B), internal appearance (C) and SS: TA ratio (D) affected by interaction storage time $\times$ cultivar. $* *, *$ and ${ }^{\circ}$ represent the significance of the parameters of the regression model at $\mathrm{p} \leq 0.01, \mathrm{p} \leq 0.05$ and $\mathrm{p} \leq 0.1$, respectively

However, for the internal appearance (IA), grades decreased during the storage in both cultivars (Figure 1C). Nevertheless, at the end of the 35 days of storage, only the 'Goldex' melon presented IA greater than 3.0, therefore considered optimal for commercialization. The low internal appearance value $(<3.0)$ of 'Iracema' melons at 35 days of storage may be related to the smaller epicarp thickness compared to 'Goldex' melon. 

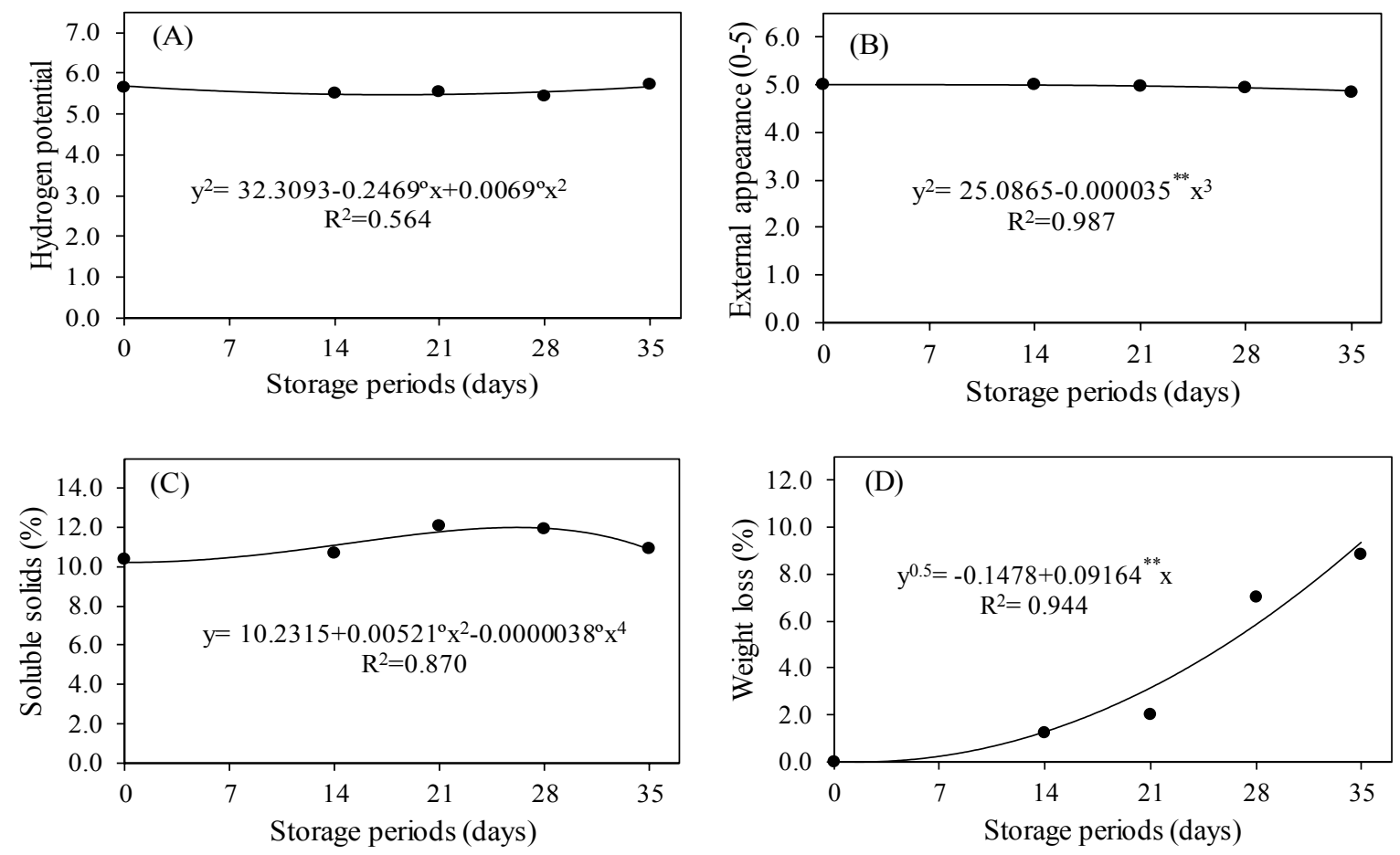

Figure 2. Hydrogen potential (A), external appearance (B), soluble solids (C), weight loss (D) affected by interaction storage time $\times$ cultivar. $* *, *$ and ${ }^{\circ}$ represent the significance of the parameters of the regression model at $\mathrm{p} \leq 0.01, \mathrm{p} \leq 0.05$ and $\mathrm{p} \leq 0.1$, respectively

The soluble solids (SS) content is an important attribute for melon marketing, since it influences the fruit flavor. An increase of $15.91 \%$ was stated in the SS content of the fruit of both cultivars up to 21 days of storage, reaching $12.02 \%$ (Figure $2 \mathrm{C}$ ). This increase may be related to the fruit weight loss and/or to a possible increase of products resulting from cell wall degradation.

After 21 days of storage, the SS content in the fruit had decreased by $9.65 \%$. Nevertheless, at the end of the storage time, the fruit SS level remained close to $10 \%$, which is considered an indicator of excellent quality (Suslow, 2012). After harvest some non-climacteric fruit the initial sugar concentration can be increased as a result of the metabolism of cell wall polysaccharides. In the case of melon, the sugar content that represents $\pm 90 \%$ of the soluble solids is determined by the time the fruit remain fixed to the plant (Kroen et al., 1991). Therefore, the decrease of soluble solids after 21 days possibly results from the consumption of sugars in the respiratory process.

A decrease in the SS:TA ratio was observed for both cultivars during storage. The SS:TA ratio of 'Iracema' fruit was highest (111.83) after 14 days, and lowest (95.61) after 21 days of storage (Figure 1D). For 'Goldex' fruit, the SS:TA ratio highest at time zero (139.29) and 127.07 after 35 days. After all but one storage time, except 14 days, the SS:TA ratio of 'Goldex' was higher than that of 'Iracema' fruit (Figure 1D), demonstrating the better quality of 'Goldex'.

During the storage the weight loss (WL) increased as a function of storage time, resulting in a final WL of $9.36 \%$. (Figure 2D). The absence of packaging probably influenced this finding. The WL observed in this study was higher than reported by Tomaz et al. (2009). However, it is noteworthy that the relative humidity used by these authors (90 and 95\%, respectively) was different from that used in our study (80\%). We verified that the WL at 35 days $(9.36 \%)$ was not enough to cause an effective loss in the commercial quality of 'Goldex' melon in terms of appearance, on the other hand, may have accentuated the decrease of internal appearance of fruits to a improper condition for marketing 'Iracema' melon.

The average diameter of the fruits was influenced only by the application of bioestimulant (Table 2). The average values of the cultivars Goldex $(14.46 \mathrm{~cm})$, Iracema $(14.08 \mathrm{~cm})$ were statistically equal. On the other hand, the application of the biostimulant contributed to the production of fruits with larger diameter, compared to the plants not treated with the product (Table 2). Bangerth (2008) emphasized that the action of growth regulators 
like cytokine increase fruit size. Likewise, Leão et al. (2005) and Souza et al. (2010) found an increased berry diameter after Crop Set ${ }^{\circledR}$ application in the grape cultivars 'Thompson Seedless' and 'BRS Clara', respectively.

Table 2. Means diameter $(\mathrm{cm})$ and internal cavity $(\mathrm{cm})$ depending on Crop Set $\AA$ applications and melon cultivars 'Goldex' and 'Iracema'

\begin{tabular}{lll}
\hline & Diameter $(\mathrm{cm})$ & Internal cavity $(\mathrm{cm})$ \\
\hline Goldex & $14.46^{\mathrm{A}}$ & $5.04^{\mathrm{B}}$ \\
Iracema & $14.08^{\mathrm{A}}$ & $5.63^{\mathrm{A}}$ \\
\hline With application & $14.86^{\mathrm{a}}$ & $5.31^{\mathrm{a}}$ \\
Without application & $13.68^{\mathrm{b}}$ & $5.36^{\mathrm{a}}$ \\
\hline
\end{tabular}

Note. Means followed by the same letter do not differ by the Tukey test at $\mathrm{p}<0.05$ probability. Uppercase letters compare melon cultivars and lowercase letters compare application of biostimulant.

The internal cavity of 'Iracema' fruit was $11.71 \%$ larger than of 'Goldex' (Table 2). Similar results were observed in the inner cavity of 'Iracema' and 'Goldex' melon by Tomaz et al. (2009), with an internal fruit cavity size similar to that of 'Goldex' $(4-5 \mathrm{~cm})$, while for'Iracema' the larger values $(6-7 \mathrm{~cm})$ were reported than found in fruit of the same cultivar in our study.

The content of total soluble sugars in fruit of both cultivars, with as well as without plant biostimulant application, was highest after 21 days of storage (Table 3). In 'Goldex', the total soluble sugar content in fruit of plants treated with Crop Set ${ }^{\circledR}$ differed only after 21 days, while without Crop Set ${ }^{\circledR}$ application, fruit differed in sugar levels 21 and 28 days, compared to the other storage time (0,14 and 35 days), and were lowest (4.96\%) after 28 days. In fruit of 'Iracema' with and without Crop Set ${ }^{\circledR}$ application, soluble sugars were highest after 21 and 28 days of storage (Table 3 ).

Table 3. Total soluble sugars of the fruit (\%) of the cultivars 'Goldex' and 'Iracema' with and without application of Crop Set ${ }^{\circledR}$ during storage

\begin{tabular}{|c|c|c|c|c|}
\hline \multirow{2}{*}{ Storage Time (days) } & \multicolumn{2}{|c|}{ Application of Crop Set ${ }^{\circledR}$} & \multicolumn{2}{|c|}{ No application of Crop Set ${ }^{\circledR}$} \\
\hline & 'Goldex' & 'Iracema' & 'Goldex' & 'Iracema' \\
\hline 0 & $6.18 \mathrm{BAa}$ & $7.59 \mathrm{Baa}$ & $6.45 \mathrm{BAa}$ & $7.86 \mathrm{Baa}$ \\
\hline 14 & 6.05 BAa & $6.52 \mathrm{Baa}$ & $6.22 \mathrm{BAa}$ & $7.26 \mathrm{Baa}$ \\
\hline 21 & $8.86 A \mathbf{A a}$ & $9.48 \mathrm{AAa}$ & $10.57 \mathrm{AAa}$ & $9.20 \mathrm{AAa}$ \\
\hline 28 & $8.52 B A \mathrm{Aa}$ & $9.23 \mathrm{AAa}$ & $4.96 \mathrm{CBb}$ & $9.33 \mathrm{AAa}$ \\
\hline 35 & $7.61 B A \mathbf{A a}$ & $6.05 \mathrm{Bab}$ & $7.27 \mathrm{BAa}$ & $8.04 B \mathbf{a a}$ \\
\hline
\end{tabular}

Note. Means followed by the same letter do not differ by the Tukey test at $\mathrm{p}<0.05$ probability. Italic capital letters compare the means within the column; bold capital letters compare the means of the cultivars within each level of application (with and without); lowercase letters compare the cultivar means with and without Crop set application.

Tomaz et al. (2009) observed that the levels of total soluble sugars in fruit of different hybrids of yellow melon decreased during storage. The sugars are energy substrates for cell metabolism and fundamental for the maintenance of vital processes in fruit after harvest (Kays, 1991).

In contrast to 'Iracema', the application of the biostimulant to plants of 'Goldex' cultivar only resulted in higher total soluble sugar levels in the fruit after 28 days of storage. Lower sugar levels (5.29\%) were detected in melon by Hayata et al. (2000) after $10 \mathrm{mg} \mathrm{L}^{-1}$ CPPU application.

With regard to the total soluble sugar content of the fruit under Crop Set ${ }^{\circledR}$ application, no statistical difference was observed between the cultivars (Table 3). However for the fruit of 'Goldex' cultivar without Crop Set ${ }^{\circledR}$ application, the percentage of total soluble sugars was lower after 28 days. Sugar accumulation during melon maturation is essential for influencing fruit acceptance directly.

\section{Conclusions}

The pre-harvest application of Crop Set ${ }^{\circledR}$ biostimulant influenced some quality characteristics of the yellow melon, depending on the cultivar and storage time. 
The use of biostimulant Crop Set ${ }^{\circledR}$ increased the length of the fruits only of 'Iracema' melon. In the 'Goldex' melon, the application of biostimulant decreased the pulp firmness and increased the $\mathrm{pH}$ of fruits.

Only at 28 days of storage, the cultivar Goldex treated with the biostimulant presented higher sugar content compared to the treatment without application

The plant growth regulator not influence fruit weight and cavity characteristics, internal and external appearance, weight loss, soluble solids content, titratable acidity and SS:AT ratio.

\section{References}

Amaro, A. L., Fundo, J. F., Oliveira, A., Beaulieu, J. C., Fernández-Trujillo, J. P., \& Almeida, D. P. F. (2013). 1-Methylcyclopropeno effects on temporal changes of aroma volatiles and phytochemicals of fresh-cut cantaloupe. Journal of the Science of Food and Agriculture, 93, 828-837. https://doi.org/10.1002/jsfa.5804

Arnau, J. A., Tadeo, F. R., Guerri, J., \& Primo-Millo, E. (1999). Cytokinins in peach: Endogenous levels during early fruit development. Plant Physiology and Biochemistry, 37, 741-750. https://doi.org/10.1016/ S0981-9428(00)86687-5

Association of Official Agricultural Chemists. (1992). Official methods of analysis of the association of official analytical chemistry. Washington, DC: Association of Official Agricultural Chemists.

Bangerth, K. F. (2008). Possible interferences of pre-harvest factors with the storage behaviour and quality of frui. Acta Horticulturae, 796, 19-29. https://doi.org/10.17660/ActaHortic.2008.796.1

Cohen, S., Itkin, M., Yeselson, Y., Tzuri, G., Portnoy, V., Harel-Baja, R., ... Schaffer, A. A. (2014). The PH genes determines fruit acidity and contributes to the evolution of sweet melons. Natute Communications, 5, 1-9. https://doi.org/10.1038/ncomms5026

Crane, J. C. (1964). Growth substances in fruit setting and development. Annual Review Plant Physiology, 15, 303-326. https://doi.org/10.1146/annurev.pp.15.060164.001511

Davies, P. J. (2010). Plant hormones: Biosynthesis, signal transduction, action! (3rd ed.). Dordrecht: Kluwer Academic Publishers. https:// doi.org/10.1007/978-1-4020-2686-7

Deng, L., Pan, X., Chen, L., Shen, L., \& Sheng, J. (2013). Effects of preharvest nitric oxide treatment on ethylene biosynthesis and solublesugars metabolism in 'Golden Delicious' apples. Postharvest Biology and Technology, 84, 9-15. https://doi.org/10.1016/j.postharvbio.2013.03.017

Ferreira, D. F. (2010). SISVAR: Sistema de análise de variância (Versão 5.3). Lavras-MG: UFLA

Goulao, L. F., Santos, J., Sousa, I., \& Oliveira, C. M. (2007). Patterns of enzymatic activity of cell wall-modifying enzymes during growth and ripening of apples. Postharvest Biology and Technology, 43, 307-318. https://doi.org/10.1016/j.postharvbio.2006.10.002

Hayata, Y., Niimi, Y., Inoue, K., \& Kondo, S. (2000). CPPU and BA, with and without pollination, affect set, growth, and quality of muskmelon fruit. HortScience, 35, 868-870.

Jandel Scientific. (1991). Table Curve: Curve Fitting Software (p. 208). Corte Madera, CA: Jandel Scientific.

Kays, J. S. (1991). Post-harvest physiology of perishable plant products. New York, NY: Van Nostrand Reinhold.

Kohatsu, D. S. (2007). Efeitos de reguladores vegetais na qualidade de frutos de melão rendilhado (Master's thesis, Universidade Estadual Paulista, Faculdade de Ciências Agronômicas, Botucatu, Brazil). Retrieved from https://repositorio.unesp.br/handle/11449/137187

Kroen, W. K., Pharr, D. M., \& Huber, S. C. (1991). Root flooding of muskmelon (Cucumis melo L.) affects fruit concentration but not leaf carbon exchange rate. Plant Cell Physiology, 32, 467-473. https://doi.org/ 10.1093/oxfordjournals.pcp.a078103

Leão, P. C. S., Silva, D. J., \& Silva, E. E. G. (2005). Efeito do ácido giberélico, do bioestimulante crop set e do anelamento na produção e na qualidade da uva 'Thompson Seedless' no vale do São Francisco. Revista Brasileira de Fruticultura, 27, 418-421. https://doi.org/10.1590/S0100-29452005000300019

Liu, L., Kakihara, F., \& Kato, M. (2004). Characterization of six varieties of Cucumis melo L. based on morphological and physiological characters, including shelf-life of fruit. Euphytica, 135, 305-313. https://doi.org/10.1023/B:EUPH.0000013330.66819.6f 
Moing, A., Aharoni, A., Biais, B., Rogachev, I., Meir, S., Brodsky, L., ... Hall, R. D. (2011). Extensive metabolic cross-talk in melon fruit revealed by spatial and developmental combinatorial metabolomics. New Phytologist, 190, 683-696. https://doi.org/10.1111/j.1469-8137.2010.03626.x

Nuñez-Palenius, H. G., Huber, D. J., Klee, H. J., \& Cantliffe, D. J. (2007). Fruit ripening characteristics in a transgenic 'Galia' male parental muskmelon (Cucumis melo L. var.reticulatus Ser.) line. Postharvest Biology and Technology, 44, 95-100. https://doi.org/10.1016/j.postharvbio.2006.12.011

Obando-Ulloaa, J. M., Nicolaib, B., Lammertynb, J., Bueso, M. C., Monforted, A. J., \& Fernández-Trujilloa, J. P. (2009). Aroma volatiles associated with the senescence of climacteric or non-climacteric melon fruit. Postharvest Biology and Technology, 52, 146-155. https://doi.org/10.1016/j.postharvbio.2008.11.007

Shin, Y. S., Park, S. D., \& Kim, J. H. (2007). Influence of pollination methods on fruit development and sugar contents of oriental melon (Cucumis melo L. cv. Sagyejeol-Ggul). Scientia Horticulturae, 112, 388-392. https://doi.org/10.1016/j.scienta.2007.01.025

Sousa, J. S., Castro, R. C., Andrade, G. A., Lima, C. G., Lima, L. K., Milhome, M. A. L., \& Nascimento, R. F. (2013). Evaluation of an analytical methodology using QuEChERS and GC-SQ/MS for the investing of the level of pesticide residues in Brazilian melos. Food Chemistry, 141, 2675-2681. https://doi.org/10.1016/ j.foodchem.2013.05.027

Souza, J. S., Castro, R. C., Andrade, G. A., Lima, C. G., Lima, L. K., Milhome, M. A. L., \& Nascimento, R. F. (2013). Evaluation of na analytical methodology using QuEChERS and GC-SQ/MS for the investigation of the level of pesticide residues in Brazilian melos. Food Chemistry, 141, 2675-2681. https://doi.org/10.1016/ j.foodchem.2013.05.027

Souza, R. T., Nachtigal, J. C., Morante, J. P., \& Santana, A. P. S. (2010). Efeitos de doses e formas de aplicação de reguladores de crescimento em uvas sem sementes, cv. BRS CLARA, em região tropical. Revista Brasileira de Fruticultura, 32, 763-768. https://doi.org/10.1590/S0100-29452010005000109

Suslow, T. V., Cantwell, M., \& Mitchell, J. (2012). Honeydew: Recommendations for maintaining post-harvest quality. Post-harvest Technology. Davis: University ofCalifornia. Retrieved from http://postharvest.ucdavis. edu/Commodity_Resources/Fact_Sheets/Datastores/Fruit_English/?uid=27\&ds=798

Taiz, L., \& Zeiger, E. (2013). Plant Physiology (5th ed.). Sunderland: Sinauer Associates.

Tomaz, H. V. Q., Aroucha, E. M. M., Nunes, G. H. S., Bezerra Neto, F., Tomaz, H. V. Q., \& Queiroz, R. F. (2009) Qualidade pós-colheita de diferentes híbridos de melão-amarelo armazenados sob refrigeração. Revista Brasileira de Fruticultura, 31, 987-994. https://doi.org/10.1590/S0100-29452009000400011

Yemn, E. W., \& Willis, A. J. (1954). The estimation of carbohydrate in plant extracts by anthrone. Biochemical Journal, 57, 508-514. https://doi.org/10.1042/bj0570508

Zhang, T., Zhang, Q., Pan, Y., Che, F., Wang, Q., Meng, X., \& Rao, J. (2017). Changes of polyamines and CBFs expressions of two Hami melon (Cucumis melo L.) cultivars during low temperature storage. Scientia Horticulturae, 224, 8-16. https://doi.org/10.1016/j.scienta.2017.05.033

\section{Copyrights}

Copyright for this article is retained by the author(s), with first publication rights granted to the journal.

This is an open-access article distributed under the terms and conditions of the Creative Commons Attribution license (http://creativecommons.org/licenses/by/4.0/). 